\title{
Governance and Risk Management: Empirical Evidence from Malaysia and Egypt
}

\author{
Rashidah Abdul Rahman ${ }^{\text {a }}$, Siti Balqis Noor ${ }^{\text {b }}$, Tariq Ismail \\ ${ }^{a}$ Professor of Accounting, Universiti Teknologi MARA, 40450 Shah Alam, Selangor,Malaysia \\ ${ }^{b}$ Universiti Teknologi MARA40450 Shah Alam, Selangor,Malaysia \\ c Professor of Accounting, Faculty of Commerce, Cairo University, Nahdat Misr, Giza 12613, Egypt, and \\ College of Business Administration, Majmmah University, Majmaah, Saudi Arabia
}

\begin{abstract}
The perceptions of Islamic banking professionals are surveyed through a questionnaire to explore whether the process of risk management mediates board involvement in risk management and risk management practices of Islamic banks in Malaysia and Egypt. The findings of this study identified that the Islamic banks in the selected countries are somewhat efficient in their risk management process. It was noticed that board involvement in risk management, process of risk management and risk management among Islamic banks in Malaysia are significantly higher than their counterparts in Egypt. Furthermore, high involvement of boards in risk management significantly increases the risk management process, and in turn, leads to significantly higher risk management practices in Islamic banks. Hence, boards should take formal responsibility for setting, managing and periodically assessing the risk management culture of the banks. It is expected that the outcomes of this study would help policy setters in the selected countries to develop a well-structured and harmonized risk management process that enhance risk management practices, with emphasis on the effective involvements of the board of directors and Shari'ah supervisory boards in risk management practices.
\end{abstract}

Keywords: Risk management; governance; Islamic banks; Basel II; Malaysia; Egypt

JEL Classification: G21, G30, M21, M48, N25, O16

\section{(C) 2013 Published by SSBFNET}

\section{Introduction}

The players in Islamic Finance have significantly increased over the years and now include not only pure Islamic institutions but also hybrid players (conventional bank with Islamic Finance windows). At one time a common fallacy was Islamic Finance was less risky than conventional financing. However, a study undertaken by the International Monetary Fund (Cihak and Hesse, 2008) provides empirical evidences which verify that Islamic finance is simply different with its own unique set of risks which can be equivalently risky as the conventional finance. An example in point is when Islamic Finance institutions like the Kuwait based Global Investment House was found to be technically insolvent in late 2008 and early 2009. Therefore, not understanding the unique risks of the Islamic Finance model (risk sharing and risk pooling) can cause a failure of the model, igniting financial crises with a ripple effect on the Islamic faith. Effective risk management in Islamic banking, thus, deserves priority attention: unless the industry develops its own genuine risk management architecture, it cannot achieve the dynamism that provides the viability needed for a more resilient financial system than the failing Wall Street model. Further, risk management in Islamic banking is still an under-researched area of study.

However, it might be difficult to enhance risk management practices in the complex banking industry without having a strong support from corporate governance practices. According to most banking laws, ultimate responsibility on risk

\footnotetext{
${ }^{\mathrm{c}}$ Corresponding author. Tariq Ismail, Tel.:(+2) 01001369557.
} 
management practices is typically placed with the boards (Greuning \& Bratanovic, 2000). Risk governance is generally defined as "board and management oversight of risk and the attendant configuration of risk management processes of identifying, measuring, managing, and reporting risk" (Ard \& Berg, 2010). Boards hold the ultimate responsibility to ensure that all risks of the bank are identified, evaluated, and suitably managed. However, the 2007 financial crisis revealed that boards failed to fulfill the task properly. Even though most of the boards acknowledged the importance of strategic risk issue, they are not taking risk management as a specific obligation of the board but they handle it under operational level, in a conventional manner (Ingley \& Van Der Walt, 2008). No time and skills might be the reason of why the boards are not taking risk management as a specific obligation but to largely rely on management in getting the true risk management view of the entity (Coulson-Thomas, 1993).

Nevertheless, risk management in conventional and Islamic banks has received little attention in emerging economies, where few studies examined the relationship between the process of risk management and risk management practices (Al-Tamimi and Al-Mazrooei, 2007; Hassan, 2009; and Abu Hussain and Al-Ajmi, 2012). The results reveal that high level of risk management process implementation inherently increases the level of risk management practices of the banks. There is no empirical study that explores the relationship between governance and risk management process and the subsequent effect on the significance of good governance on the effectiveness of risk management practices. Therefore, the current study fills this gap by examining the effects of governance on both risk management process and risk management practices. Our study differs from prior research on risk management in emerging markets in a number of ways. For example, Ismail (2012) concludes that the majority of Egyptian conventional banks is employing a risk management framework to identify and manage properly the various risks that they face. Hence, his results do not provide empirical evidence on the proper applications of risk management process or its effectiveness on risk management practices. Therefore, we extend Ismail's study by looking at the impact of risk management process on the risk management practices of Islamic banks in emerging economies, where this line of research is needed, as concluded by the Pacific Economic Cooperation Council (PECC) study of 2002 on Indonesia, Korea, Chinese Taipei, and Thailand; where results reveal that most Asian banks still lack experience in the effective application of risk management. Unlike Al-Tamimi and Al-Mazrooei (2007), Hassan (2009); and Abu Hussain and Al-Ajmi (2012), who examine the relationship between the process of risk management and risk management practices, we additionally test the influence of governance on risk management practices.

We believe that the impact of governance on risk management process and risk management practices of Islamic banks in emerging economies is too important to leave unaddressed. Hence, there is an opportunity to carry out indepth investigation on this line of research on Malaysia and Egyptian practices to examine such impact. This paper seeks to find answers to the following questions in relation to Islamic banks in Malaysia and Egypt:

Q1: Do risk management process affects the level of risk management practices?

Q2: Do board involvement in risk management affect the level of risk management process?

Q3: Does an effective risk management process, as a result of board's involvement, enhance a high level of risk management practices?

Thus, the main objective of the paper is to provide further insights and explores the relationship between governance, risk management process and risk management practices in the context of Islamic Financial Institutions, which are run on the Islamic legal and economic system, which prohibits Riba (interest), avoids Gharar (uncertainty), avoids Maysir (gambling or excessive speculation).Specifically, this study examines whether the process of risk management mediates board involvement in risk management on risk management practices of Islamic banks in Malaysia and Egypt through the perceptions of participants who were drawn from the Islamic banking and finance industry from these two countries. The research maps out the opinions and attitudes towards the board involvement in the risk management process and locates the practices of the industry related to risk management.

The findings of this study have policy-making implications which could benefit regulators, policy makers, Shari'ah scholars, practitioners, academia, and institutional stakeholders. Furthermore, this study has filled a gap in the literature by empirically exploring governance and risk management issues from an Islamic banking perspective and providing some useful insights that improvement in boards oversight function will lead to effective risk management practices in Islamic Financial Institutions.

Taking the Malaysian and Egyptian Islamic banking cases, the next section is reviewing the literature and the hypotheses development on the relationship between governance, risk management processes and risk management 
practices. Subsequently, section three discusses the method undertaken by this study and nature of data collection and data sources. This is followed by the analysis of the results in section four, and finally, discussions and conclusions are presented in section five.

\section{Literature Review and Hypotheses Development}

The fundamental structures of the traditional financial system were questioned after the financial crisis in 2007 (Kassim \& Majid, 2010) and investors and others began to search for other alternatives. Facing the global financial crisis, banks in developing countries such as Malaysia and Egypt react to replicate Islamic banking principles by reducing banking rates and offering null-approximating interest rates (Trabelsi, 2011). Islamic financing institutions then started to promote their Shari'ah compliant model of asset-based and risk sharing financing as a safer and more enduring approach (Rarick \& Han, 2009). Because of the model, Islamic banks are able to avoid the losses of loans and securities during the downturn. Therefore, it is believed that, Shari'ah principles have sheltered Islamic banks from financial shock, as Islamic banks were not affected as much as the conventional banks (Hassan \& Dridi, 2010; Kassim \& Majid, 2010).

The asset-based and risk sharing model has successfully avoided Islamic banks from the losses of loans and securities during the downturn (Rarick \& Han, 2009). However, even though the crisis had a limited impact on Islamic banking institutions, it did not emerge totally unscathed. The unique structure also exposes Islamic banks to face more risk as Islamic banks are not permitted to use some risk management instruments because of Shari'ah compliance regulations. This has reduced the ability of Islamic banks to deal with risk as well as the means available to these banks for balancing claims and assets (Elgari, 2003). Hence, it is found that Islamic banking institutions in Malaysia and Egypt are also vulnerable to macroeconomic impacts and financial shocks, similar to conventional banks (Kassim \& Majid, 2010). Because of that, the Central Bank of Malaysia (BNM) and Central Bank of Egypt (CBE) suggested Islamic banks to maintain a high level of risk management practices, with policies and procedures deliberated and employed are consistent with the institution's corporate strategy and functioning as directed.

The Basel accords require that risk management policies and procedures be disclosed by all banks with risk definitions, measurement methods and mitigation strategies being disclosed in a bank's annual report. For most Islamic banks, however, risk management seems to be a 'black box', where only a few common items are disclosed with no further details provided (Salem, 2012). Banks should have adequate and advanced processes for managing risks so they would be in favor of disclosing important risk management strategies.

The current paper explores the relationship between risk management process, risk management practices and the effects of board involvement on the effectiveness and the level of the risk management practices. Hence, several hypotheses are developed that identify and link governance to risk management process and practices.

\subsection{Risk management process}

Islamic banks are following Basel II and at the same time, they are recommended to follow the issued guidelines on risk management of the Islamic Financial Service Board (IFSB). IFSB suggested that Islamic banks must have a proper process that is to understand, identify, measure, analyze, monitor and report different types of risk for a good risk management practice as a whole. This will help banks to handle risk, as they have little or no control on risk, but they are capable to control on the level of processes to handle risk, which will lead to a high level of risk management practices of the bank. Rosman (2009) highlight the important aspects of the risk management process, which includes understanding risk, risk identification, risk assessment and analysis and risk controlling and monitoring. On the other hand, empirical studies on risk management processes have been done by Al-Tamimi and Al-Mazrooei (2007), Hassan (2009), and Abu Hussain and Al-Ajmi (2012). Hassan (2009) and Abu Hussain and Al-Ajmi (2012) examined the relationship of the risk management process in Islamic banks in Brunei and Bahrain, respectively, to the level of its risk management practices. Hassan (2009) found that risk identification and risk assessment are the most influencing risk management's aspects in Bruneian Islamic banks. Hassan (2009) and Abu Hussain and Al-Ajmi (2012) also found that high level of the risk management process implementation inherently increases the level of risk management practices of the banks. Thus, the current study hypothesized that high level of risk management process implementation will significantly increase the level of risk management practices of Islamic banks in Malaysia and Egypt, accordingly, the first hypothesis is formulated as below:

H1: There is a positive relationship between the risk management process and the level of risk management practices. 


\subsection{Board Involvement in Risk Management}

In a nutshell, an effective risk management practice deserves an enormous consideration. However, it might be difficult to enhance risk management practices in the complex banking industry without having a strong support from corporate governance practices. According to most banking laws, ultimate responsibility on risk management practices is typically placed with the boards (Greuning \& Bratanovic, 2000). Various arguments and theories on the role of the board on risk are found in the literature as discussed by Chong (2004), Ingley and Van Der Walt (2008), Bates II and Leclerc (2009), Krus and Orowitz (2009), Bugalla, Hacket, Kallman and Narvaez (2010), Young (2010) and Lipton, Rosenblum \& Cain (2011).

In agency theory, appointing board of directors is one of the mechanisms which are used to solve the agency problem, the divergence of management's interest from fulfilling stakeholders' interest to their own selves' interest (Eisenhadt, 1989). Therefore, Basel Committee on Banking Supervision (BCBS, 2006), Islamic Financial Service Boards (IFSB) and the Central Bank of Malaysia, Bank Negara Malaysia (BNM) and Central Bank of Egypt (CBE) outlined that board of directors must actively oversight risk management activities in Islamic banks. It requires the Board and senior management to identify, evaluate monitor and control or mitigate all material risks and to access their overall capital adequacy. Thus, it is vital for the board to maintain its cooperation with executive-level risk management committee to set risk appetite and tolerance (Bugalla et al., 2010). However, the board must be rational towards the degree of tolerance given to the CEO to prevent them from being dominant in board agendas. Therefore, the board must have experience and expertise in finance to successfully assess risks that are beyond the data presented by CEO (Strebel \& Lu, 2010; Young, 2010). The board should convince themselves that the risk management process executed are able to mitigate risk and protected from any Shari'ah non-compliance risk. Even though, the process is also required to be managed at the management-level, it is emphasized that boards hold the ultimate responsibility to ensure that all risks of the bank are identified, evaluated, and suitably managed.

Bates and Leclerc (2009) found that even when there is a separate risk management committee created, the boards still have to be involved heavily in risk oversight. In order to effectively carry out its risk oversight duties, a board must ensure that the bank has a risk management program adapted to its industry needs. The board also must periodically review the program with the company's senior risk officers, general counsel and outside consultants to assess the effectiveness of the program, and then addresses any issues that arise from its monitoring or investigation accordingly" (Krus \& Orowitz, 2009).

Further, management will be inspired to perform at a high level if their board of directors is performing as transformational leaders or portraying an Islamic leadership model which can cause a positive influence to the management (Mclaurin \& Al-Amri, 2008, Mir, 2010). Aligned to the Islamic leadership model based on the primary Muslim sources which are the Holy Quran and the Sunnah (the teaching of Prophet Muhammad P.B.U.H), the transformational leadership theory shows that both leaders and followers raise one another to a higher level of morality and motivation. Both models stress the need for achieving higher and noble goals contributing to others betterment, going beyond the self-interest of the individual. Thus, without direct support and involvement from the board it is impossible to make risk management effective. More importantly, the board needs to regularly revise risk management policies implemented by the risk managers and ensures that the culture of "risk-aware and risk-adjusted decision making" are fostered throughout the organization (Lipton et al., 2011). In other words, when boards involve themselves in the risk management process, the process of risk management will be performed at a high level, resulting in higher risk management practices.

As the board's role is important in risk management, it is thus hypothesized that board's involvement in risk management will give a significant positive impact on the level of risk management processes (more specifically the risk understanding, risk identification, risk analysis and risk monitoring), hence, the second hypothesis is:

H2: There is a positive relationship between board's involvement in risk management and the level of risk management process.

This study further hypothesized that as board involvement in risk management can predict the level of risk management processes implemented, inherently leads to a higher level of risk management practices in the Islamic bank. The highest level of risk management process may be able to positively affect risk management practices of the Islamic banks as a whole based on the premise that when the board of directors is performing as transformational 
leaders which can cause a positive influence to the management practice (Mclaurin \& Al-Amri, 2008). This leads to the following third hypothesis:

H3: The high level risk management process leads to significant higher risk management practices.

\section{Method}

\subsection{Research design}

This paper treats the risk management process as a mediator variable that is affected by governance, which in turn, affects the level of risk management practices as shown in Figure 1 along with reference to the hypotheses to be tested. It can be noted that Figure 1 depicts the expected relationships among the independent variable, the mediator and the dependent variable. Step 1 (Path a) tests the effect of mediating variable (process of risk management) on the dependent variable (risk management practices). Step 2 (Path b) tests the effect of the independent variable (boards involvement in risk management) on the mediator (process of risk management) while Step 3 (Path c) tests the effect of the independent variable (boards involvement in risk management) on the dependent variable (risk management practices). Both relationships of IV and DV and IV and ME must be significantly related respectively. Step 4 (Path c'), the mediator (process of risk management) must be significantly related to the dependent variable (risk management practices) and the effect of the independent variable (boards involvement in risk management) on the dependent variable (risk management practices) should be zero. In step 4, it must be shown that the effect of board involvement in risk management on risk management practices -controlling for process of risk- management should be zero.

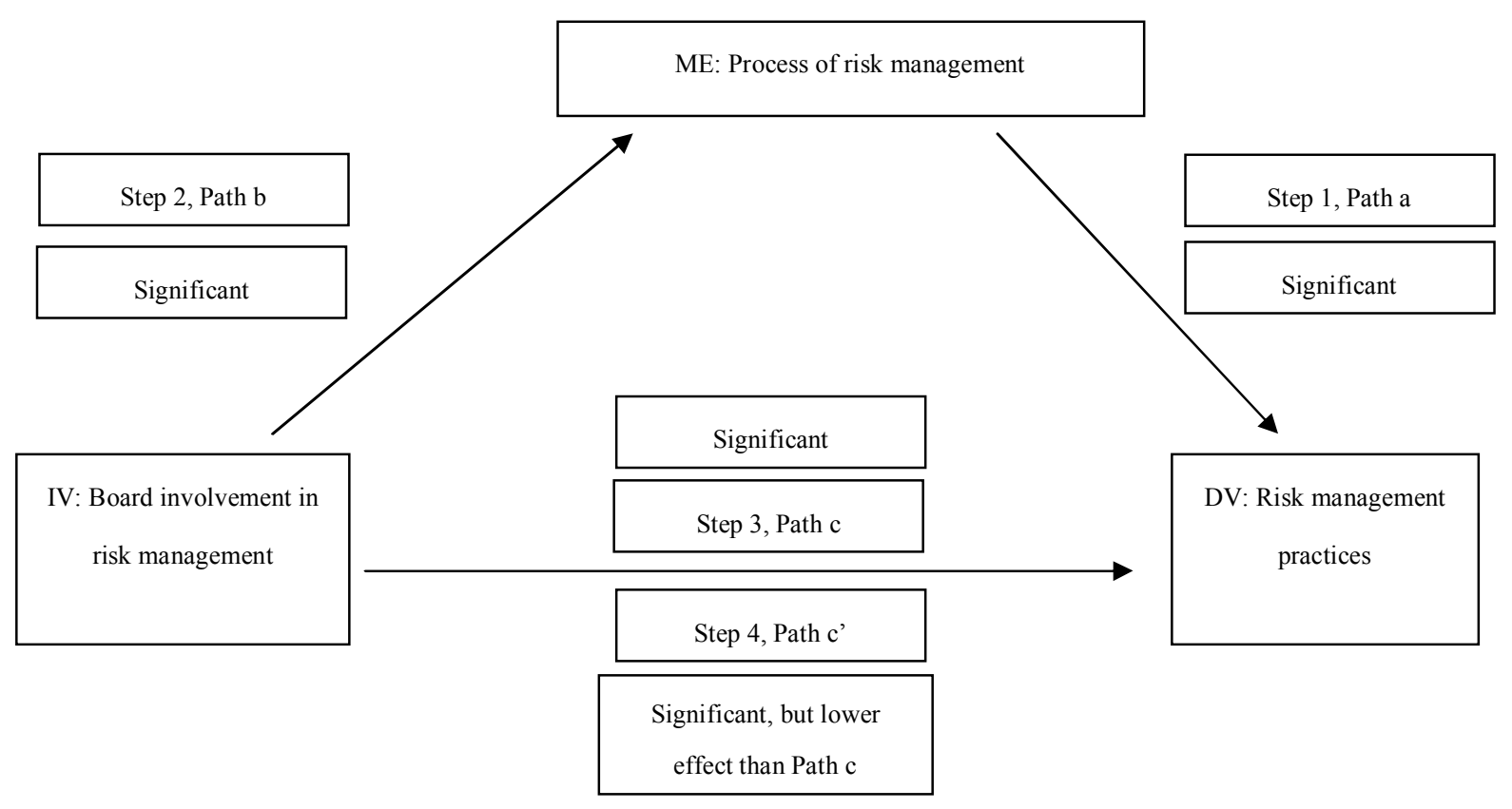

Figure 1. The Expected Results from Four Hierarchical Regressions

(Where, $M E=$ mediator variable, $I V=$ independent variable, $D V=$ dependent variable)

\subsection{Data sources}

Banking institutions disclose only minimal details of their risk management programs, and, as a result, most empirical analyses have to rely on surveys. Case studies of individual organizations, while providing greater detail on banking practices, typically lack cross-sectional variation to test whether existing theories of governance explain risk management practices. Thus, a survey questionnaire was developed by extending the methodology of Al-Tamimi and Al-Mazrooei (2007), Hassan (2009), and Abu Hussain and Al-Ajmi (2012) to suit the objective of this study. The 
questionnaire differs from that of previous studies in two aspects: it includes an additional section on the impact of governance on risk management practices. Further, to access the scales content validity related to the questionnaire survey, six experts (five practitioners from five Islamic banks in Malaysia and one academician) were involved in the pilot testing, as suggested by Devellis (1991). The revised questionnaire was distributed during the months of September-December 2011 in Malaysia and February-April 2012 in Egypt. Questionnaires were distributed and returned by post, through email or by walk-in collection. The method of distribution varied, based on the banks' preference.

The questionnaire was segregated into five main parts: the respondent's profile; the company's profile; the risk management process namely: understanding risk management, risk identification, risk assessment and analysis, and risk monitoring; general risk management practices; and governance on risk management practices. Respondents were asked to indicate, on a 7-point Likert Scale (ranged from 1= strongly disagree" to 7="strongly agree", their perceptions on a total of 44 closed-ended questions related to risk management process (11 questions), boards involvements in risk management (5 questions) and risk management practices ( 29 questions).

\subsection{Sample selection}

The target population of this survey includes departments that deal with risk management in Islamic banks. As of 30 June 2011, there were 17 Islamic banks in Malaysia (listed under Bank Negara Malaysia), while in Egypt, there were 3. Fifteen questionnaires were distributed to each of the banks totaling 300; 255 in Malaysia and 45 in Egypt. The valid data for Malaysia is 119 questionnaires and in Egypt is 17, which gives a total sample of 136 observations.

\subsection{Study models}

The relationships between governance, risk management process and risk management practices are examined by estimating the coefficients in four multiple regression models after considering the mediating effects. Four hierarchical models are used in four steps as below:

Model (1): tests the relationship between 'process of risk management' and 'risk management practices'.

Model (2): tests the link between 'board involvement in risk management' and 'process of risk management'.

Model (3): tests the influence of 'board involvement in risk management' on 'risk management practices'.

Model (4): depicts the link between the mediator; process of risk management, and the board's involvement in risk management and risk management practices relationship.

\section{Data Analysis and Findings}

\subsection{Reliability test}

Reliability of the measures used in the questionnaires was assessed by using Cronbach's $\alpha$; which measure the reliability of different variables. In the estimation, a coefficient greater than or equal to 0.7 is considered acceptable and a good indication of reliability. As shown in Table 1, Cronbach's $\alpha$ for risk management practices (RMP), the process of risk management (PRM) and board involvement in risk management (BOD) for both countries are greater than 0.7 , indicating that all three variables are reliable.

Table 1: Reliability of the measures

\begin{tabular}{lllll}
\hline No. & Variables & \multicolumn{2}{c}{ Cronbach's $\alpha$} \\
& & Malaysia & Egypt & Overall (Both) \\
\hline 1 & Risk management practices (RMP) & 0.887 & 0.901 & 0.903 \\
2 & Process of risk management (PRM) & 0.888 & 0.940 & 0.922 \\
3 & Board involvement in risk management (BOD) & 0.870 & 0.893 & 0.876 \\
\hline
\end{tabular}




\subsection{Descriptive statistics}

Table 2 highlights the descriptive results for Malaysia, Egypt, and both countries combined. The T-test significant level shows that Malaysia and Egypt are statistically different in the mean of all the three variables; where the value lies below the cut-off of 0.05 . Generally, board involvement in risk management, process of risk management and risk management among Islamic banks in Malaysia are significantly higher than their counterparts in Egypt. However, on average the results indicate that boards in Islamic banks in Malaysia and Egypt are highly involved in risk management, with a mean score of 5.32. The boards and Shari'ah supervisory boards are on average "generally high" in their involvement in understanding risk and risk management; risk identification; risk assessment and analysis; and risk control and monitoring.

The respondents in both countries also indicate that their understanding of the risk management process (understanding risk and risk management; risk identification; risk assessment and analysis; risk control and monitoring) is high with a mean of 5.81. These results are consistent with those of Al Tamimi and A-Mazrooei (2007), Hassan (2009), and Abu Hussain and Al-Ajmi (2012) where UAE banks, Brunei Islamic banks and Bahrain banks respectively, are somewhat efficient in the risk management process.

Table 2: Descriptive statistics

\begin{tabular}{lcccccc}
\hline Malaysia & $\begin{array}{c}\text { Mean } \\
\text { Egypt }\end{array}$ & $\begin{array}{c}\text { Total } \\
\text { Sample }\end{array}$ & $\begin{array}{c}\text { T-test Sig. } \\
\text { Level }\end{array}$ & Skewness & Kurtosis \\
\hline $\begin{array}{l}\text { Board involvement in risk } \\
\text { management }\end{array}$ & 5.39 & 4.83 & 5.32 & 0.03 & -0.163 & -0.072 \\
$\begin{array}{l}\text { Process of risk management } \\
\text { Risk management practices }\end{array}$ & 5.92 & 5.02 & 5.81 & 0.00 & -1.508 & 2.378 \\
\hline
\end{tabular}

Furthermore, the questionnaire includes questions about risk management process. Hence, Table 2 also shows that the respondents' responses to the questions to be on average 5.74, which indicate that the Islamic banks in Malaysia and Egypt are efficient in risk management practices. The highest mean value among the questions about risk management practices is 5.98; which relates to the question "one of the objectives of Islamic banks is to have effective risk management practices". Besides implementing Shari'ah compliance risk management practices, the Islamic banks in Malaysia and Egypt also indicate that they have training programs to enhance staff knowledge in risk management practices.

\subsection{Regression results}

Multiple regression model is used to determine which of the hypothesized explanatory variables affect the likelihood of an Islamic bank in creating a high level of risk management practices, and whether boards involvement in risk management affect the level of risk management processes. Several assumptions in regression analysis have been tested. The results of multicollinearity tests reveal that all the correlation coefficients between the independent variables are less than 0.9 , thus no multicollinearity exists (Pallant, 2001). Homocedasticity assumption was tested based on an analysis of residuals and plots of the studentised residuals against predicted values. As recommended by Pallant (2001), observations with studentised residuals of more than 3.00 are omitted from the analysis. Furthermore, normality tests based on skewness, kurtosis and Kolmogorov-Smirnov were also conducted. Transformation is undertaken for both independent and dependent variables when it does not meet the assumptions of normality.

Further, the strategy of Baron and Kenny (1988) is adopted to identify whether the process of risk management is a mediating variable. Mediators are intervening variable that explain how the initial variable affected dependent variable. As shown previously, Figure 1 portrays the expected directional relationships in the four hierarchical regression models hence, the results of the multiple regression analysis are summarized in the following four steps:

\section{Step 1: the relationship between 'Process of risk management' and 'risk management practices'}

Step 1 tests whether the mediator (process of risk management) affects the outcome variable (risk management practices). This is to estimate and test path a in Figure 1. It is not sufficient to just correlate the mediator with the 
dependent variable; the mediator and the outcome may be correlated because they are both caused by the independent variable (board involvement in risk management). Thus the independent variable must be controlled in establishing the effect of the mediator on the outcome.

As shown in Table 3, the $\mathrm{R}$ square value for testing the initial variable on the outcome is 0.581 . This explains that $58.1 \%$ of the variance in risk management practices is predicted by the process of risk management. The F-statistics show that the relationship is significant $(\mathrm{F}=92.149, \mathrm{p}<0.01)$. The effect of the process of risk management on risk management practices is also shown by standardize coefficient which equals to 0.739 . The positive value indicates that the direction of the relationship is positive. As predicted, the level of risk management practices increases when there is an increase of the process of risk management level in Islamic Banks, thus the first hypothesis is accepted. AlTamimi and Al-Mazrooei (2007) and Abu Hassan (2009) also provide evidence on the positive relationship between risk management practices and the various aspects of the risk management process in UAE banks and Brunei Islamic banks, respectively.

Table 3: Risk management process and risk management practices relationships

\begin{tabular}{llll}
\hline & R-square & F & Sig. \\
\hline Predictor: Process of risk management & 0.581 & 92.149 & 0.000 \\
Dependent variable: Risk management practices & & & \\
\hline
\end{tabular}

\section{Step 2: the relationship between 'Board' involvement in risk management' and 'process of risk management'}

In step 2, the independent variable or the predictor (boards involvement in risk management) must be correlated with the mediator (process of risk management). This need to be done to estimate and test path $b$ in figure 1 . This step essentially involves treating the mediator as if it was an outcome variable.

Table 4 highlights that the $\mathrm{R}$ square value for testing the initial variable on the outcome is 0.029 . This explains that $2.9 \%$ of the variance in risk management practices is predicted by board involvement in risk management. Even though only a small amount of variance is explained in risk management practices by board involvement in risk management, the F-statistics show that the relationship is significant $(\mathrm{F}=3$. 997, $\mathrm{p}<0.05)$. The effect of board involvement in risk management on risk management practices is also shown by standardize coefficient which equals to 0.170 . The positive value indicates that the direction of the relationship is positive. As predicted, the level of process of risk management increases when there is an increase of board involvement in risk management level in Islamic banks, thus the second hypothesis is accepted.

Table 4: Boards involvement in risk management and risk management process relationships

\begin{tabular}{llll}
\hline & R-square & F & Sig. \\
\hline $\begin{array}{l}\text { Predictor: Boards involvement in risk management } \\
\text { Dependent variable: Process of risk management }\end{array}$ & 0.029 & 3.997 & 0.048 \\
\hline
\end{tabular}

\section{Step 3: the relationship between 'Board' involvement in risk management' and 'risk management practices'.}

Next, the independent variable (board involvement in risk management) must be correlated with the dependent variable (risk management practices). This is to estimate and test Path $\mathrm{C}$ in Figure 1. As shown in Table 5, the $\mathrm{R}$ square value for testing the initial variable on the outcome is 0.051 and the F-statistics show that the relationship is significant $(\mathrm{F}=7.131, \mathrm{p}<0.01)$. This explains that $5.1 \%$ of the variance in risk management practices is predicted by board involvement. The effect of board involvement in risk management on risk management practices is also shown by standardize coefficient which equals to 0.225 . The positive value indicates that the level of risk management practices increases when there is an increase of board involvement in risk management level in Islamic Banks in 
Malaysia and Egypt. Therefore, the criterion of step 3 is met: independent variable is significantly related to the dependent variable.

Table 5: Board involvement in risk management and risk management practices relationships

\begin{tabular}{llll}
\hline & R-square & F & Sig. \\
\hline $\begin{array}{l}\text { Predictor: Board involvement in risk management } \\
\text { Dependent variable: Risk management practices }\end{array}$ & 0.051 & 7.131 & 0.009 \\
\hline
\end{tabular}

\section{Step 4: the process of risk management as a mediator between boards and risk management practices}

In order to establish that process of risk management completely mediates the board involvement in risk management and risk management practice relationship, there is a need to explore that the effect of board involvement in risk management on risk management practices controlling for process of risk management is zero. This is to estimate and test path c' in Figure 1. If the effect of path c' does not reach zero but found to be lower than the path $\mathrm{c}$, then the process of risk management partially mediates the relationship.

Table 6 presents the effect of the intervention on the risk management practices, controlling for the mediator; process of risk management. It can be noted that the effect of path c' is 0.099 which is lower than the effect of path c; which has the effect of 0.225 . The total reduction is 0.126 due to the process of risk management $(0.170$ times 0.739$)$. Therefore, based on such reduction, $56 \%$ of the total effect is explained. Additionally, step 4 shows that the process of risk management partially mediates the relationship between board involvement in risk management and risk management practices. It means that when boards involvement in risk management are at high level, it significantly increases risk management process level and, in turn, the high level risk management process leads to significant higher risk management practices. Therefore, the third hypothesis is accepted.

Table 6: Summarized results of the relationships between risk management process, risk management practices and board's involvements in risk management

\begin{tabular}{llll}
\hline Independent variable & $\begin{array}{l}\text { Step 1/4. DV: Risk } \\
\text { management practices }\end{array}$ & $\begin{array}{l}\text { Step 2. ME: Process of risk } \\
\text { management }\end{array}$ & $\begin{array}{l}\text { Step 3. DV: Risk } \\
\text { management practices }\end{array}$ \\
\hline $\begin{array}{l}\text { Process of risk } \\
\text { management }\end{array}$ & $\begin{array}{l}\text { Path a: } \\
\beta=0.739,\end{array}$ & \\
& $\mathrm{P}=0.000$ (significant) & & \\
& & & \\
& & & \\
$\begin{array}{l}\text { Board involvement in risk } \\
\text { management }\end{array}$ & $\begin{array}{l}\text { Path c': } \\
\beta=0.099\end{array}$ & $\begin{array}{l}\text { Path b: } \\
\beta=0.170,\end{array}$ \\
& (lower effect than path c) & $\mathrm{P}=0.048$ (significant) & $\beta=0.225$, \\
& & & $\mathrm{P}=0.009$ (significant)
\end{tabular}

\section{Conclusions}

To fulfill the aims of this study, the perceptions of banking professionals on whether the process of risk management mediates board involvement in risk management and risk management practices of Islamic banks in Malaysia and Egypt are surveyed through a questionnaire. The final survey sample comprised 136 observations from the two countries.

In general, the findings of this study identify the strength among Islamic banks in the area of risk management and governance. Islamic banks in Malaysia and Egypt had complied with the suggestions made by IFSB (2005), BCBS (2006) and the Central Bank of the respective countries to have in place a comprehensive risk management and 
reporting process, including appropriate board and senior management oversight, to identify, measure, monitor, report and control relevant categories of risk. Similar to the findings of Al-Tamimi and Al-Mazrooei (2007) in UAE banks, Abu Hassan (2009) for Islamic banks in Brunei and Abu Hussain and Al-Ajmi (2012) for Bahrain banks, the current study found that the Islamic banks in Malaysia and Egypt are somewhat efficient in their risk management process that includes understanding risk and risk management; risk identification; risk assessment and analysis; and risk control and monitoring.

It was noticed that board involvement in risk management, process of risk management and risk management among Islamic banks in Malaysia are significantly higher than their counterparts in Egypt. This can be justified on the ground that Malaysia has a quite number of Islamic banks than those in Egypt, hence, risk management at banks is wellstructured to identify, measure, monitor and report risk; where all business units report their identified risks to an independent Risk Management Officer who is responsible for the aggregation of all material risks and reporting directly to Senior Management and to the Supervisory Regulatory Body as the case may be. Furthermore, units in charge have to oversee the implementation of all relevant risk policies, developing tools to assist senior management to determine risk appetite and assessing the overall risk profile of the bank.

Additionally, the Islamic banks in the two countries have also ensured that the risk management process has taken into account appropriate steps to comply with Shari'ah rules and principles and ensured the adequacy of relevant risk reporting to the board. Similarly, the respondents perceived that their Islamic banks are reasonably efficient in risk management practices and that the banks have successfully implemented the IFSB, Basel II and Central Bank guidelines in regards to their risk management systems.

Furthermore, the findings of the study provide evidence that boards must take a pro-active stance in overseeing the risk management framework as part of the development assurance framework across the organization. Concurrent with the agency theory, high involvement of boards in risk management will significantly increase risk management process, and in turn, leads to significant higher risk management practices in the organization. Thus, boards should take formal responsibility for setting, managing and periodically assessing the risk management culture of the organization. In doing so, the board of directors and senior management must be qualified and well-versed in the nature of the risks involved in the Islamic banking business.

In the light of the above discussion, Table 7 summarizes the results of testing of hypotheses, where the findings suggest a positive relationship between the risk management process and the level of risk management practices as well as between board's involvement in risk management and the level of risk management process. Hence, the first and the second hypotheses are supported. Furthermore, the results suggest that the high level risk management process leads to significant higher risk management practices, accordingly, the third hypothesis is supported.

Table 7: Summary of hypotheses testing

\begin{tabular}{lll}
\hline H1 & $\begin{array}{l}\text { There is a positive relationship between the risk management process and the level of risk management } \\
\text { practices. }\end{array}$ & Supported \\
H2 & $\begin{array}{l}\text { There is a positive relationship between board's involvement in risk management and the level of risk } \\
\text { management process. }\end{array}$ & Supported \\
H3 & The high level risk management process leads to significant higher risk management practices. & Supported \\
\hline
\end{tabular}

Further, management will be inspired to perform at a high level if their board of directors is performing as transformational leaders or portraying an Islamic leadership model which can cause a positive influence to the management. These include connecting the management's sense of identity and self to the mission of the organization, particularly on the importance to cultivate an effective risk management culture in these banks to ensure their competitiveness and survival in a world of uncertainties and crises. Additionally, it is expected that the outcomes of this study would help policy setters to develop a well-structured and harmonized risk management process that enhance risk management practices, with emphasis on the effective involvements of the board of directors and Shari'ah supervisory boards in risk management practices. 
There is an opportunity to carry out further research to examine the board's oversight of assurance across the banks, particularly examining the existence and the relationship between risk management group, the internal audit department and other internal assurance providers and their impact on enhancing risk management practices.

\section{Acknowledgements}

We would like to thank Accounting Research Institute, Universiti Teknologi MARA Malaysia and the Malaysia Ministry of Higher Education for the financial grant received in conducting this research.

\section{References}

Abu Hussain, H. \& Al-Ajmi, J. (2012). Risk management practices of conventional and Islamic banks in Bahrain. The Journal of Risk Finance, 13 (3), 215 - 239

Ackoff, R. L. (1999). Transformational leadership. Strategy \& Leadership, 27 (1), 20.

Al-Tamimi, H. A. H., \& Al-Mazrooei, F. M. (2007). Banks' risk management: a comparison study of UAE national and foreign banks. The Journal of Risk Finance, 8(4), 394-409.

Ard, L., \& Berg, A. (2010). Bank governance: lessons from the financial crisis, crisis response. Public policy for the private sector, (World Bank, Washington).

Arifin, N. M., Archer, S., \& Karim, R. A. A. (2008). Risks in Islamic banks: evidence from empirical research. Journal of Banking Regulation, 10(2), 153-163.

Bank Negara Malaysia. (2011). Capital adequacy framework for Islamic banks - internal capital adequacy assessment process (Pillar 2). Available at: http://www.bnm.gov.my/guidelines/01_banking/01_capital_adequacy/11_gl_002_22_pillar2.pdf (accessed July 5, 2011).

Baron, R. M., \& Kenny, D. A. (1986). The moderator-mediator variable distinction in social psychological research: conceptual, strategic and statistical considerations. Journal of Personality and Social Psychology, (51), $1173-1182$.

Bates II E.W \& Leclerc R.J. (2009). Boards of directors and risk committees. The Corporate Governance Advisor, 17, (6), 15-17.

BCBS (2006). Core principles methodology, Basel Committee on Banking Supervision, Bank for International Settlements.

Bugalla J., Hackett, J., Kallman, J. \& Narvaez, K. (2010). Putting board risk committees to work, The Corporate Board, 31(185), 21-25.

Bukhari, S. (1999). Sayings of Al-Bukhari (Volume 3, Book 46, Number 733). available at: http://www.scribd.com/doc/20921310/Sahih-Bukhari, 582.

Champion, D. (2008). Lesson from the crisis: risk management has limits. available at:

http://blogs.hbr.org/hbr/hbreditors/2008/10/lesson_from_the_crisis_risk_ma.html (accessed July 7, 2011).

Chong, Y. Y. (2004). Corporate governance: risk management starts at the top. Balance Sheet, 12(5), 42-47.

Cihak, M., \& Hesse, H. (2008). Islamic banks and financial stability: an empirical analysis. International Monetary Fund (IMF) working paper No. 08/16.

Coulson-Thomas, C. (1993). Developing directors-building an effective boardroom team. England: McGRAW-HILL Book Company Europe.

Dusuki, A. W. (2008). Corporate governance and stakeholder management: ans Islamic approach. In S. M. Yamaludin \& N. Harun (Eds.), Essential readings in Islamic Finance (pp. 391-413). Kuala Lumpur: CERT Publications Sdn Bhd.

Eisenhardt, K. M. (1989). Agency theory: an assessment and review. The Academy of Management Review, 14(1), 5774. 
Elgari, M. A. (2003). Credit risk in Islamic banking and finance. Islamic Economic Studies, 10(2), 2-25.

El-Qorchi, M. (2005). Islamic finance gears up. Finance and Development, 42(4), 46.

Garnier, M. (2008). Black holes in risk governance. Journal of Risk Management in Financial Institutions, 2(2), 116120.

Greuning, H. V. \& Bratanovic, S. B. (2000). Analyzing banking risk. Washington: The International Bank for Reconstruction and Development/ THE WORLD BANK.

Hassan, A. (2009). Risk management practice of Islamic banks of Brunei Darussalam. The Journal of Risk Finance, 10(1), 23-37.

Hassan, M., \& Dridi, J. (2010). The effects of the Global crisis on Islamic and conventional Banks: a comparative study. Journal of International Commerce, Economics and Policy, 2(2), 163-200.

How, J. C., karim, M. A., \& Verhoeven, P. (2005). Islamic financing and bank risks: The case of Malaysia. Thunderbird International Business Review, 47(1), 75-94.

Imam, P., \& Kpodar, K. (2010). Good for growth. Finance \& Development, 47, 44-45.

Ingley, \& Walt, V. D. (2008). Risk management and board effectiveness. International Studies of Management and Organization, 38(3), 43-70.

Ismail, T. H. (2012), Internal auditors' perception about their role in risk management audit in Egyptian banking sector, International Journal of Economics \& Accounting, 3 (2), 196-220.

Kassim, S. H., \& Majid, M. S. A. (2010). Impact of financial shocks on Islamic banks: Malaysian evidence during 1997 and 2007 financial crises. International Journal of Islamic and Middle Eastern Finance and Management, 3(4), 291-305.

Kendrick, J. S. (2011). Transformational leadership: changing individuals \& social systems. Professional Safety, $56(11), 14$.

Kenny, D. A. (2012). Mediation. availabe at: http://davidakenny.net/cm/mediate.htm (accessed April 3, 2012).

Krus, C. M., \& Orowitz, H. L. (2009). The risk-adjusted board: how should the board manage risk?. The Corporate Governance Advisor, 17(2), 1-6.

Lipton, M., Rosenblum S.A. \& Cain K.L. (2011). Some thoughts for boards of directors in 2012. available at: http://ssrn.com/abstract=2020413 (accessed September 15, 2011).

McLaurin, J. R., \& Amri, M. B. A. (2008). Developing an understanding of charismatic and transformational leadership. Paper presented at the Allied Academies International Conference, USA.

Mir, A. M. (2010). Leadership in Islam. Journal of Leadership Studies, 4(3), 69-72.

Muljawan, D. (2008). Risk management in Islamic finance issues, challenges and strategies to mitigate the risk. In Bakar, M.D. \& Ali, E.R. (Vol. Ed.). Essential readings in Islamic finance. Kuala Lumpur: CERT Publications Sdn. Bhd.

OECD (Organization for Economic Co-operation and Development). 2004. OECD Principles of corporate governance. Paris.

Pacific Economic Cooperation Council- PECC (2002), Bank ownership and risk management in the Asia-Pacific region: divergence and convergence of practice, Malaysia.

Pallant, J. (2001). SPSS Survival Manual. Australia: Allen \& Unwin Book Publisher.

Rarick, C. A., \& Han, T. (2009). Islamic finance: panacea for the global financial system? Journal of Applied Business and Economics, 11(3), 27-32.

Ringshaw, G. (2007). US bank collapse is largest in 14 years. available at: http://business.timesonline.co.uk/tol/business/industry_sectors/banking_and_finance/article2557195.ece (accessed July 1, 2011) 
Rosman, R. (2009). Risk management practices and risk management processes of Islamic banks: a proposed framework, International Review of Business Research Paper, 5 (1), 242-254.

Sabato, G. (2010). Financial crisis: where did risk management fail?. International Review of Applied Financial Issues and Economics, 2(2), 315-328.

Salem, R. (2012), Risk management in Islamic banks: the black box phenomenon, New Horizon, 19 May, available at: http://www.newhorizon- islamicbanking.com/index.cfm?action=view\&id= 11413\&section=features (accessed June 27, 2012).

Smolo, E., \& Mirakhor, A. (2010). The global financial crisis and its implications for the Islamic financial industry. International Journal of Islamic and Middle Eastern Finance and Management, 3(4), 372-385.

Strebel, P., \& Lu, H. (2010). Risk management starts at the top. Business strategy review, 21(1), 18-23.

Taleb, N. N., Goldstein, D. G., \& Spitznagel, M. W. (2009). The six mistakes executives make in risk management. Harvard Business Review, October, 78-81.

Tchankova, L. (2002). Risk identification - basic stage in risk management. Environmental Management and Health, 13(3), 290-297.

Trabelsi, M. A. (2011). The impact of the financial crisis on the global economy: can the Islamic financial system help?. The Journal of Risk Finance, 12(1), 15-25.

UBS (2008). Shareholder report on UBS' Write-Downs. available at: http://www.ubs.com/ (accessed July 20, 2011).

U.K. Treasury, (2009). A review of corporate governance in UK banks and other financial industry entities: final recommendations, Walker Review. available at: http://www.hm-treasury.gov.uk/ (accessed September 15, 2011).

Yatim, P. (2009). Audit committee characteristics and risk management of Malaysian listed firms. Malaysian Accounting Review, 8(1), 19-36. 